https://doi.org/10.22364/hssl.28.1.01

\title{
WIND FARM PROJECT RESULTS AND INNOVATIVE BUSINESS MODELS
}

\section{Karina Viskuba}

Mg. oec.

\section{Veronika Silinevicha}

Mg. oec.

\begin{abstract}
Currently, the subject of renewable energy resources (RES), including wind energy, is very important in the context of environment, energy, investment and business issues, therefore the technical and political development of RES is rapid and the operating environment - ever-changing.
\end{abstract}

Keywords: Latvia, renewable energy, wind power, financial plan

\section{Introduction}

The energy industry all around the world is currently undergoing changes due to the development of new technologies, user requirements and restrictions on the availability of natural resources, which are stimulating companies to expand and revise their business, offer new services and open up new markets. Increasing global demand for energy, limited supplies of fossil fuels, as well as environmental pollution and the threat of global climate change have led to increased interest in renewable energy sources. The use of renewable energy sources is considered a key element of energy policy, reducing dependence on fuel imported from third countries, reducing emissions from fossil fuels and decoupling energy costs from oil prices.

In the modern world everything is connected - as one industry changes, so do others and the chain continues to infinity. The energy field also does not stand still. Not only technology, but also business models in the energy sector are developing. The importance of one of these models will be discussed in this article.

More effective use of Europe's energy potential requires the involvement of all energy market players. The core of any business model is a consumer. A consumer is the point of reference that defines the vector of business development. Today, the energy industry is undergoing a transformation where the consumer is no longer just a point; it turns into a vector itself. 
Decentralization of the power system through the involvement of active consumers, citizens and local authorities in the operation of the system is currently widely used in Europe. Active consumers are defined as electricity consumers that use, store or sell their own electricity or participate in demand change and energy efficiency schemes.

Methodology: This study is based on literature and statistical data bases review, comparative analysis. The result of literature review, statistical data bases and comparative analysis were presented into tables and diagram.

Period of research: from 2001 to 2019 year.

\section{General Sector Overview}

The use of energy is the key to humanity. It helps to develop and adapt to the changing environment. Today's society consumes enormous amounts of energy, so the energy sector is very important worldwide. Energy supports all aspects of modern life, contributing to economic growth and prosperity, thus has a direct link to people's living standards.

Based on the statistical classification of economic activities in the European Community, NACE Rev. 2, the industry is classified as:

- D section "Electricity, gas, steam and air conditioning supply"

- 35 "Electricity, gas, steam and air conditioning supply"

- 35. 1 "Electric power generation, transmission and distribution"

- 35. 1.1 "Production of electricity". This class includes: - the production of electricity from cogeneration units, nuclear power plants, hydroelectric power stations, gas turbines or diesel generators and from renewable energy sources. [4]

According to the Central Statistical Bureau last data, there were 347 economically active commercial companies (market sector) in Latvia at NACE D 35.11 in 2017. The Latvian enterprise database Lursoft, shows that in March 2019, 489 companies with this NACE code were registered in Latvia.

Before getting an idea of the future development prospects of the industry, the authors will explore the trends of the industry in recent years, gather available information, experts' opinions and formulate conclusions.

\section{Recent Developments}

The authors begin with the industry contribution to one of the most important indicators of the country's economic development - gross domestic product. Although GDP is commonly used at constant prices, which takes into account inflation, to compare the volume of goods and services, the authors examined the contribution of industry to GDP in real (average) prices, which includes changes in output and price. 
There are three main sources of electricity generation in Latvia - hydroelectric power stations, large cogeneration units and other cogeneration units. To a much lesser extent, electricity is generated from small hydro, wind and biogas plants. This fact confirms the promising growth and development of this industry sector.

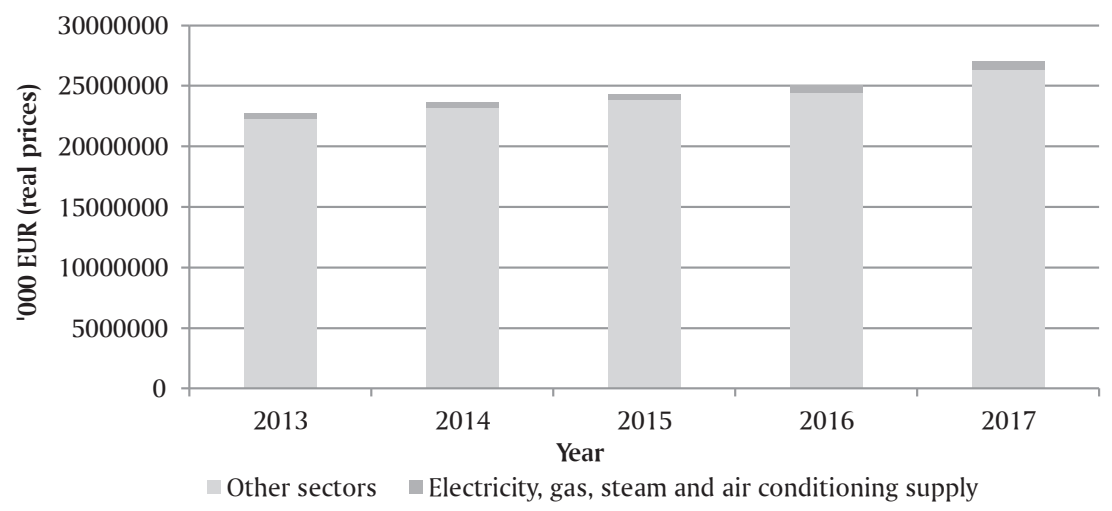

Figure 1. Electricity, Gas, Steam and Air Conditioning Supply Share in Latvia's GDP 2013-2017 years, real prices, '000 EUR [7]

Source: Created by the authors

Figure 1 shows the share of electricity, gas, heating and air conditioning in the GDP of Latvia in the period 2013-2017. The graph is in absolute terms, but the authors have given a percentage to make it easier to understand the sector's share of GDP. Summarising the results, it can be stated that the average contribution of the industry to the national GDP is $2.23 \%$ during the five years given. The largest increase was in 2016, from $2.09 \%$ share in 2015 to $2.55 \%$ in 2016 . The industry made the smallest contribution to GDP in 2014 , calculated $1.78 \%$ in total volume that year. The sector's contribution to Latvia's GDP has been stable over the years, with positive growth prospects. (See Figure 1)

The production and consumption of energy resources is a major factor in the global economy. The energy sector is stimulated by global energy supply and demand. Latvia belongs to those countries that are heavily dependent on imported energy resources because they are unable to fully meet the required electricity consumption. The volumes of electricity import, export and consumption in Latvia for the period 2014-2018 were defined.

According to the Latvia's Central Statistical Bureau, there have been no significant fluctuations in final energy consumption over the last 
decade. The major consumers of energy resources are the transport sector, agriculture, forestry, households. According to Figure 2 the consumption has a minimal tendency to grow. Over the last 25 years, there has been a gradual development of production, transmission and distribution through new projects, renovations and repairs. Along with the increase in production, the export of electricity has also increased. During the five years shown on the graph, there is no uniform trend in electricity import, it is fluctuating. In 2017, Latvia's export exceeded import. Latvian domestic generation covered $101 \%$ of electricity consumption. Compared to 2016 , export increased by $9 \%$ in 2017 , import fell by $15.6 \%$ and consumption grew by $1.7 \%$. JSC "Augstsprieguma tīkls" (AST) mention in electricity market report that hydroelectric power plants (HPP) production increased by $74 \%$ in 2017 , thermal power plants (TPP) production decreased by $34 \%$, wind farms connected to transmission production increased by $0.03 \%$ and the electricity volumes generated by renewable and supported electricity producers (biomass, biogas, wind power plants, hydroelectric power stations, solar power plants) with installed capacity up to $10 \mathrm{MW}$ increased by $6 \%$. [11] The amount of electricity generated by hydroelectric power plants influenced the reduction of fossil fuel power station generation volumes and was a major contributor to the positive energy balance. In 2017, Latvia's total electricity production was $7346336 \mathrm{MWh}$; compared to 2016 the increase was equal $18 \%$. (See Figure 2)

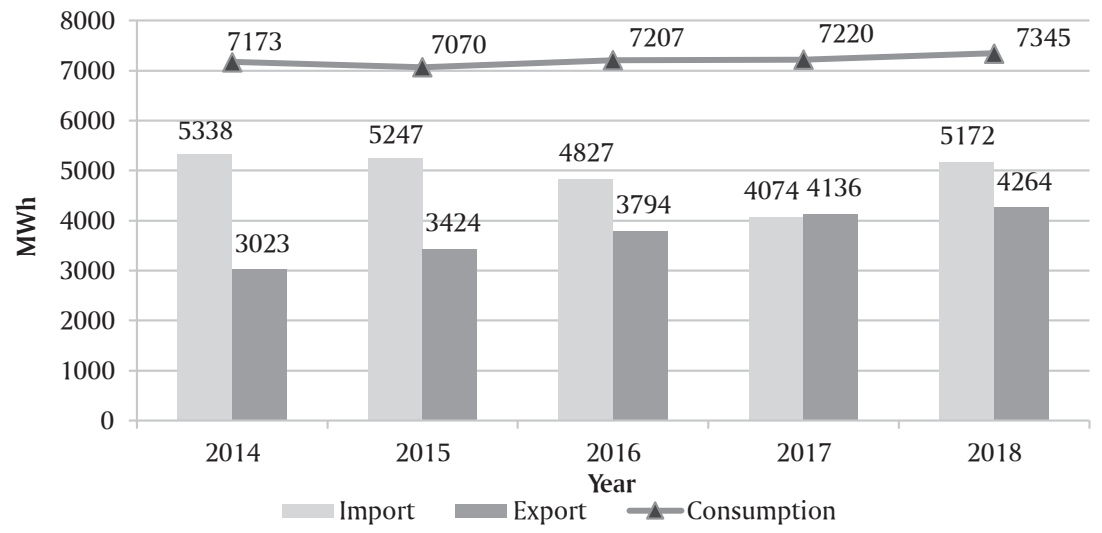

Figure 2. Latvia's Electricity Import, Export and Consumption 2014-2018 years, MWh [7]

Source: Created by the authors

Turning to the Latvia's development trends of renewable energy sources (RES), the authors wish to mention the topical issues of RES 
defined by Latvian Wind Energy Association, which mentions two factors: "Latvia's great dependence on energy resources from Russia and the desire of the country to increase self-sufficiency and independence in this area; There is a tendency in the world, and especially in Europe, to increase the use of green or renewable energy in our daily lives." [20]

The use of wind resources is the second largest form of electricity generation in Europe. On average, wind farms in the EU operate at $35 \%$ onshore and $50 \%$ offshore, with total installed wind turbines of approximately $178.8 \mathrm{GWh}$ in 2018.

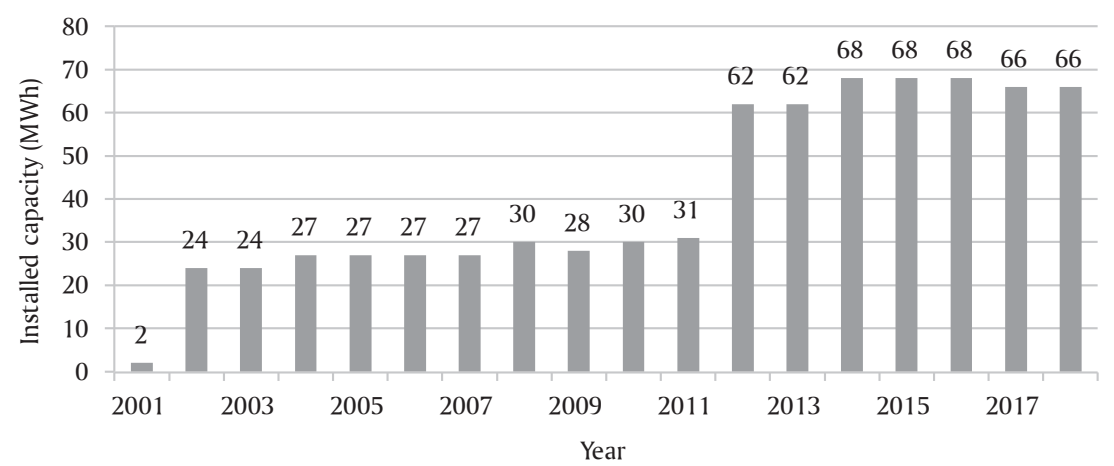

Figure 3. Total Installed Capacity of Latvia's Wind Turbines in 2001-2018, MWh [19]

Source: Created by the authors

The first wind generators in Latvia were installed in 1995, but their total installed capacity was insignificant. The total installed capacity in 2001 was only $2 \mathrm{MWh}$, but next year it increased significantly (to $24 \mathrm{MWh}$ ). The next leap was observed in 2012, when installed capacity increased rapidly to $62 \mathrm{MWh}$. This rapid increase can be explained by the start of exploitation period of several plants, including the producer Ltd. "Winergy", with installed capacity of 20.07 MW. (See Figure 3)

The total installed capacity of wind turbines in Latvia is now about $66 \mathrm{MWh}$, which allows to produce about $1.8 \%$ of the electricity consumed. In contrast, in Estonia, the installed capacity is more than $300 \mathrm{MWh}$ (about 8.5\% of electricity consumed) and in Lithuania more than $500 \mathrm{MWh}(10.5 \%$ of electricity consumed). Denmark was the leader in wind power generation in the European Union in 2018, where wind power contributes significantly to the electricity balance, it makes $41 \%$ of total electricity consumption in Denmark. In the second place was Ireland with $28 \%$, followed by Portugal 
Humanities and Social Sciences: Latvia (Volume 28(1))

with $24 \%$. In 2018 , wind energy made $14 \%$ of total electricity demand in the European Union and increased for 2\% compared to 2017.

\section{Prospects for sector development}

In November, 2018 The European Commission published a strategic long-term vision for a prosperous, modern, competitive and neutral economy for 2050. The strategy reflects on how Europe can move forward towards climate neutrality by developing new technological solutions and coordinating important areas such as industry, finance and research. It will be based on the new energy policy system created in accordance with the "Clean Energy for All Europeans" package, which gives the European consumers rights to become active participants in the energy transition stage and sets two new goals for the EU for 2030: at least a 32\% renewable energy target and at least a $32.5 \%$ energy efficiency target - with a possible upwards re-calculation. For the electricity market it sets a $15 \%$ interconnection target by 2030. Miguel Arias Cañete, the EU Commissioner for Climate Action and Energy, states that the EU is on the right track to achieve the RES target, indicating that Europe is the world's first major economy that is planning on becoming climate-neutral by 2050 and reaching an $80 \%$ RES target. These statements will promote the competitiveness, overall growth and employment of the European industry, decrease electricity costs, help prevent energy loss and improve quality. [3]

EU 2030 Energy Strategy targets:

- decrease the greenhouse effect gas emission level by $40 \%$ in comparison to 1990 ;

- at least $27 \%$ of renewable energy consumption;

- improve energy efficiency at the EU level by at least $27 \%$ (in comparison to the prognosis) which must be reviewed until 2020 (namely, the EU level is 30\%);

- support the improvement of the internal energy market by reaching the electricity interconnection target $-10 \%$ by 2020 , in order to reach $15 \%$ by 2030 . [5]

In the Republic of Latvia, the Parliament has issued a development planning document of the highest importance - "Sustainable Development Strategy of Latvia until 2030" - that defines the renewable and safe energy target for the development of the country's energy independence by increasing the energy resource self-sufficiency and integrating in the EU energy network. The strategy is comprised of certain energy development measures, projects and national targets for determining the energy and energy resource self-sufficiency. The main criteria for achieving energy sufficiency and availability is a balanced, effective, economically, socially and ecologically-based further development of the industry. To meet 
the set objectives, an industry-specific target and action document that covers the essential dimensions of the energy industry - "2030 Energy Strategy" - was created. In order to determine the national priorities for 2030, 7 tightly interrelated directions are put forward:

- decrease electricity and natural gas import from existing third world country suppliers by $50 \%$;

- achieve the reduction of building heating consumption to $100 \mathrm{kWh} / \mathrm{m}^{2}$;

- achieve a 50\% renewable energy resource proportion in the final energy consumption as well as increase the renewable energy consumption in transportation;

- guarantee alternative solutions for the supply of natural gas and legal circumstances for opening the natural gas market in Latvia in 2015;

- create electricity and natural gas markets;

- increase the cross-border electricity interconnection capacities in order to reduce the price differences in different energy exchange auction areas;

- offer support for creating an attractive environment for investments and developing the national economy by promoting the transition to energy efficient technologies and reducing energy costs for its users. [17]

Some of these objectives have already been obtained, some of them partially, but only a common and effective implementation of these performance indicators can guarantee a sustainable development of the energy industry.

Renewable energy resources will mostly dominate when prognosing Europe's offer. It is expected that by 2050 wind energy will amount to approximately $30 \%$ of the total production capacity. Regarding fossil power, it is planned to build mostly natural gas power plants in Europe. By 2050, nuclear energy and coal power station capacity will decrease to $10 \%$ of the total installed capacity. Overall the fossil production capacity will be reduced from $50 \%$ to $30 \%$.

Market value is the weighted average price of the electricity that wind power stations can immediately market. In this regard, only the hours with positive prices are taken into account. The realizable value of wind energy will increase until 2040 and then will remain at a high level regardless of the increase of the installed capacity and simultaneous cannibalisation effect. (The cannibalisation effect is understood as the loss on sales that come from introducing a new product that substitutes an older product from the same group instead of increasing the combined market shares of the company.) Sales volumes will slightly decrease. Some hours of 
emergency electricity prices are used by wind power stations that generate positive income during these hours. [2]

Dansk Energi, which is a non-commercial lobby organisation for Danish energy companies, assumes that through support schemes and auctions, politicians will ensure that the "green" transition of the electricity system continues until 2030, making wind and solar energy about half of the electricity production. [9]

\section{Financial Plan and Risk Analysis of the Project}

One of the most important parts of any project is financial planning. Financial planning is implemented to find out how much money is needed for a project to be viable and how to use it in order to optimize costs, identify revenue, determine the payback period, profitability, liquidity etc.

\section{Assumptions for the financial forecast}

20 complex assumptions were made for the financial forecast, the main ones being:

Land. In February 2020 it is planned to purchase 171.5 ha of land for the implementation of the project with a total price of EUR 220 457. The transaction is expected to be settled in an instant payment in February 2020.

Fixed Assets. Seven wind turbines will be purchased in March 2020, installed in July 2020 and commissioned in August. The payment will be settled as follows: $50 \%$ with immediate payment, $25 \%$ in April and another $25 \%$ in May.

Connection of the Station to the Power Transmission System. As an electricity transmission system operator JSC "Augstsprieguma tīkls" has a standing commitment to ensure the participants of the system the necessary connections to the transmission system. The author of the research assumes that the costs for installing all of the necessary connections stated in the project will amount to 23 million EUR. It is expected that the work will begin in April 2020. The bill for the services provided by the TSO can be settled accordingly: $40 \%$ with immediate payment, $20 \%$ in May, $20 \%$ in June and $20 \%$ in July.

Production. It is assumed that the production volume of one wind turbine will amount to $400 \mathrm{MW}$ (taking into account the instability of the wind, possible technical difficulties and losses). It is planned to install 7 wind turbines that will generate $2800 \mathrm{MW}$ per month accordingly. All of the generated electricity volume is being sold. The production process will begin in September 2020. Compensation for the generated and sold 
electricity will be settled as follows: $50 \%$ in the month concerned, $45 \%$ the following month and 5\% in the month after that.

Electricity Price Prognosis. Taking into account the 2018 summary, the authors prognose that the price of electricity in Latvia in 2020 will be approximately 50.5 EUR/MW, in 2021 53.4 EUR/MW, in 2022 56.0 EUR/MW, in 2023 58.4 EUR/MW, in 2024. 60.7 EUR/MW. To find out the approximate monthly price for each year, the authors compiled historical Latvian electricity prices on the "Nord Pool" power exchange (2014-2018), determined the monthly price share in the average price, calculated the fiveyear average monthly coefficients and determined their ratio to annual forecasted prices and thus created a price profile. (See Table 1)

Table 1. The Forecasted Electricity Price Division Per Month from 2020 to 2024, EUR/MW

\begin{tabular}{|l|l|l|l|l|l|}
\hline \multicolumn{1}{|c|}{ Month| Year } & & & & & \\
\hline January & 50.12 & 52.99 & 55.57 & 57.96 & 60.24 \\
\hline February & 45.81 & 48.44 & 50.79 & 52.97 & 55.06 \\
\hline March & 42.80 & 45.26 & 47.46 & 49.49 & 51.44 \\
\hline April & 43.15 & 45.63 & 47.85 & 49.90 & 51.87 \\
\hline May & 46.86 & 49.55 & 51.96 & 54.19 & 56.32 \\
\hline June & 54.24 & 57.35 & 60.15 & 62.73 & 65.20 \\
\hline July & 54.59 & 57.73 & 60.54 & 63.14 & 65.62 \\
\hline August & 54.65 & 57.79 & 60.60 & 63.20 & 65.69 \\
\hline September & 54.75 & 57.89 & 60.71 & 63.31 & 65.80 \\
\hline October & 56.20 & 59.43 & 62.32 & 64.99 & 67.55 \\
\hline November & 53.90 & 56.99 & 59.77 & 62.33 & 64.78 \\
\hline December & 48.94 & 51.75 & 54.27 & 56.60 & 58.83 \\
\hline $\begin{array}{l}\text { Average price, } \\
\text { EUR: }\end{array}$ & 50.50 & 53.40 & 56.00 & 58.40 & 60.70 \\
\hline
\end{tabular}

Source: Created by the authors

Insurance expenses. The project will be covered by an all-risk insurance for the equipment which can be estimated at EUR 110000 per year. This amount will be divided into 12 equal parts ( $9166.67 \mathrm{EUR} / \mathrm{month}$ ) and will be paid the following month after calculation. The beginning of the insurance period coincides with the exploitation period of the power plant (August 2020). 
Table 2. Planned Profit and Loss Statement from 01.01.2020. until 31.12.2024., EUR

\begin{tabular}{|c|c|c|c|c|c|c|c|c|}
\hline & Jan. & Feb. & Mar. & Apr. & May & Jun & Jul. & Aug. \\
\hline Net turnover & 0 & 0 & 0 & 0 & 0 & 0 & 0 & 0 \\
\hline $\begin{array}{l}\text { JSC formation } \\
\text { expenses }\end{array}$ & 380 & & & & & & & \\
\hline $\begin{array}{l}\text { Station connection to } \\
\text { the system }\end{array}$ & & & & 23000000 & & & & \\
\hline \multicolumn{9}{|l|}{ Maintenance Expenses } \\
\hline Insurance expenses & & & & & & & & 9167 \\
\hline $\begin{array}{l}\text { Power transmission } \\
\text { system's service costs }\end{array}$ & 0 & 0 & 0 & 0 & 0 & 0 & 0 & 0 \\
\hline $\begin{array}{l}\text { Fixed and intangible } \\
\text { asset amortization }\end{array}$ & & 51 & 51 & 51 & 51 & 51 & 51 & 51 \\
\hline Work salaries & 4400 & 4400 & 4400 & 4400 & 4400 & 4400 & 4400 & 4400 \\
\hline $\begin{array}{l}\text { State mandatory } \\
\text { insurance } \\
\text { contributions }\end{array}$ & 1060 & 1060 & 1060 & 1060 & 1060 & 1060 & 1060 & 1060 \\
\hline Risk fee & 1 & 1 & 1 & 1 & 1 & 1 & 1 & 1 \\
\hline $\begin{array}{l}\text { Costs of the parent } \\
\text { undertaking for } \\
\text { transactions in } \\
\text { the Nord Pool } \\
\text { exchange }\end{array}$ & 183 & 183 & 183 & 183 & 183 & 183 & 183 & 183 \\
\hline Utilities & 120 & 120 & 120 & 120 & 80 & 80 & 80 & 80 \\
\hline $\begin{array}{l}\text { Wind forecast } \\
\text { expenses }\end{array}$ & 33 & 33 & 33 & 33 & 33 & 33 & 33 & 33 \\
\hline $\begin{array}{l}\text { Stationery and office } \\
\text { maintenance expenses }\end{array}$ & 400 & & & & & & 200 & \\
\hline Accounting expenses & 400 & 400 & 400 & 400 & 400 & 400 & 400 & 400 \\
\hline Legal service expenses & 60 & 60 & 60 & 60 & 60 & 60 & 30 & 30 \\
\hline $\begin{array}{l}\text { Loan processing } \\
\text { expenses }\end{array}$ & 945 & & & & & & & \\
\hline $\begin{array}{l}\text { Other economic } \\
\text { activity-related } \\
\text { expenses }\end{array}$ & 3 & 3 & 5003 & 5003 & 5003 & 3 & 3 & 3 \\
\hline Interest payments & & 233 & 230 & 226 & 223 & 219 & 215 & 212 \\
\hline \multicolumn{9}{|l|}{ Property tax } \\
\hline $\begin{array}{l}\text { Profit before } \\
\text { corporate income tax }\end{array}$ & -7985 & -6544 & -11540 & -23011537 & -11493 & -6490 & -6656 & -15619 \\
\hline \multicolumn{9}{|l|}{ Corporate income tax } \\
\hline Net profit & -7985 & -6544 & -11540 & -23011537 & -11493 & -6490 & -6656 & -15619 \\
\hline
\end{tabular}

Source: Created by the authors 


\begin{tabular}{|c|c|c|c|c|c|c|c|c|}
\hline Sept. & Oct. & Nov. & Dec. & TOTAL & TOTAL & TOTAL & TOTAL & TOTAL \\
\hline \multirow[t]{4}{*}{21900} & 22480 & 21560 & 19576 & 85516 & 256320 & 268796 & 280324 & 291360 \\
\hline & & & & 380 & 0 & 0 & 0 & 0 \\
\hline & & & & 23000000 & 0 & 0 & 0 & 0 \\
\hline & & & & 0 & 6000 & 6000 & 6000 & 6000 \\
\hline 9167 & 9167 & 9167 & 9167 & 45833 & 110000 & 110000 & 110000 & 110000 \\
\hline 417 & 417 & 417 & 417 & 1667 & 5000 & 5000 & 5000 & 5000 \\
\hline 79385 & 79385 & 79385 & 79385 & 317897 & 952478 & 952465 & 952465 & 952465 \\
\hline 6200 & 6200 & 6200 & 6200 & 60000 & 74400 & 74400 & 81600 & 81600 \\
\hline 1494 & 1494 & 1494 & 1494 & 14454 & 17923 & 17923 & 19657 & 19657 \\
\hline 1 & 2 & 2 & 2 & 19 & 26 & 26 & 26 & 26 \\
\hline 183 & 183 & 183 & 183 & 2190 & 2190 & 2190 & 2190 & 2190 \\
\hline 80 & 80 & 120 & 120 & 1200 & 1200 & 1200 & 1200 & 1200 \\
\hline \multirow[t]{2}{*}{33} & 33 & 33 & 33 & 390 & 390 & 390 & 390 & 390 \\
\hline & & & & 600 & 400 & 400 & 400 & 400 \\
\hline 400 & 400 & 400 & 400 & 4800 & 3600 & 3600 & 3600 & 3600 \\
\hline \multirow[t]{2}{*}{30} & 30 & 30 & 30 & 540 & 360 & 120 & 120 & 120 \\
\hline & & & & 945 & 0 & 0 & 0 & 0 \\
\hline 3 & 3 & 3 & 3 & 15036 & 36 & 36 & 36 & 36 \\
\hline \multirow[t]{2}{*}{208} & 205 & 201 & 197 & 2369 & 2077 & 1530 & 963 & 376 \\
\hline & 1057 & & & 1057 & 1057 & 1057 & 1057 & 1057 \\
\hline \multirow[t]{2}{*}{-75699} & -76173 & -76073 & -78053 & -23383862 & -920817 & -907541 & -904381 & -892758 \\
\hline & & & & 0 & 0 & 0 & 0 & 0 \\
\hline-75699 & -76173 & -76073 & -78053 & -23383862 & -920817 & -907541 & -904381 & -892758 \\
\hline
\end{tabular}




\section{Profit and Loss}

The profit and loss statement shows the operating income, expenses and differences, or profit or loss over a given period. In order to create Profit and Loss, the authors made additional calculations regarding turnover, salary, depreciation and loan repayment.

The biggest expenses of 2020 are comprised of the position "Station connection to the system", but, seeing as it is a one-off event, expenses do not appear in this position in the following periods. The expenses for the formation of the JSC and for the loan processing can also be added to the one-off expenses.

The biggest expenses of the following periods reside in insurance, amortization of the fixed assets, salaries and the expenses associated with them. The biggest amortization expenses of fixed assets come from the wind turbines ERCON E-115 which are the most expensive of all the fixed assets purchased by the company. (See Table 2) By reviewing the work salaries, the authors of the research would like to refer to the above-mentioned assumptions about the increase of the work salary from 2023 when the overall costs will increase from 74400 EUR a year to 81600 EUR a year thus also increasing the employer's state mandatory insurance contributions.

By reviewing the profit and loss statement, attention must be drawn to the fact that the company will be working with losses during all of the prognosed years. The funds that the company has received in the certain year are smaller than the funds that have been spent in the same timeframe. The biggest losses form in the first operational year which can be explained by the uptake of economic activity and the acquisition of fixed assets. In the following years large funds must be allocated to amortization as well as the expenses needed to cover insurance and wage costs. However, the negative PLS outcome decreases with every year, supported by the increasing income of principal activity which will be influenced by the increase of electricity prices. (See Table 2)

\section{Project cash-flow statement}

Cash-flow is the cash or other cash equivalent turnover in a company. Funds are needed for the realisation of any kind of economic activity but they are limited, therefore the company must evaluate how to divide these funds effectively so that they last a certain period of time. Cashflow statement allows determining how to rationally spend existing funds. An accurately comprised cash-flow allows predicting the approximate situation of funds in the company, evaluate different risk factors and predict the potential influence of these risks on the company's future activity, predict various scenarios, predict payments and their deadlines 
etc., as well as react timely to shortages and problems in case of necessity. Cash-flow statement is valuable both for the management of the company and the potential investors to understand if the invested funds will bring sufficient return. The project cash-flow is constructed using the direct method taking into account assumptions previously put forward.

The net cash flow of the company is negative in its first year of operation due to the investment of large funds into to the operational launch of the company, however, in the following years it stays positive and is characterised by an increasing trend. Positive cash flow means that the company has a tendency for growth and is capable of meeting obligations, investing in development, guaranteeing back-up for future financial problems and raising outside capital.

\section{Project balance sheet}

After reviewing the profit and loss and cash-flow statements all the expenses must be combined in a balance sheet. The balance sheet establishes a balance between operating funds and their sources. The assets of the balance represent how the company has used the existing funds whilst the liabilities show where the funds have come from and what the sources (equity funds, loan) are. [14]

At the founding moment of the project on January 1st, 2020, funds 59000000 EUR - are represented in assets of the balance whilst liabilities are represented in the fixed assets. After purchasing the production facilities in 2020 the company is not planning on purchasing any large fixed assets of monetary value therefore their value decreases. The number of debtors also gradually decreases but the money assets increase. Upon successfully repaying the loan, long-term commitments decrease. A decrease in short-term commitments is also observed but they exist in relation to the expenses that will be settled in the following periods.

\section{Project evaluation}

The goal of project evaluation is to ascertain the quantitative and qualitative results by taking into account the specificity of the project. Several parties are interested in the evaluation of the project - developer, creditor, investors, suppliers etc. Several tasks can be defined in the evaluation process, for example, assessment of the financial situation, the clarification of changes and their reasons, the evaluation of development opportunities in the company and claiming new markets, evaluation of achievement of the project objectives and error assessment etc. Evaluation is intended for the analysis and improvement of the adopted decisions, the determination of the effectiveness of the use of available resources and feedback. Within the framework of the project, methods of evaluation 
such as repayment period, the net present value, internal rate of return, earnings before profit, taxes, depreciation and amortization, the return on equity and return on invested capital were used. Some of the obtained results will be reflected.

Project payback period (PP). In the case of the project, taking into account the large funds invested in the realization of the project, electricity production and price, other expenses and the life expectancy of wind turbine activity (which is 20-25 years), it could be argued that the project payback period will be longer than the life-span of the wind turbines which makes the PP calculation inexpedient in real life. For the project to be profitable within the life expectancy of the wind turbines, it is necessary to acquire substantial financial support.

Earnings Before Interest, Taxes, Depreciation and Amortization (EBITDA). As it can be ascertained from the name, EBITDA stands for earnings before interest, taxes, depreciation and amortization. It is a method used to evaluate the operational results of the company. Many investors use EBITDA to compare companies with different capital structures or fiscal jurisdictions. Assuming that two companies are profitable, the EBITDA comparison could be helpful to investors in determining which company is faster-growing from a product selling standpoint. EBITDA can be used as an interstage to evaluate the cash flow available for paying the debt for long-term assets, for example, equipment and other items (with a life expectancy longer than 10 years). EBITDA is calculated using the formula [3.1]:

EBITDA $=$ Profit/ (loss before taxes and fees + interest payments + depreciation of fixed assets and intangible assets) [3.1]

Table 3. Profit Before Interest, Taxes and Depreciation from 2020 to 2024, EUR

\begin{tabular}{|l|l|l|l|l|l|}
\hline Period, Year & & & & & \\
\hline EBITDA, EUR & -23048065 & 52744 & 65460 & 69788 & 80824 \\
\hline
\end{tabular}

Source: Created by the authors

EBITDA is negative in the first year which, as in previous calculations, can be explained by the beginning of economic activity, but an increasing trend can be observed in the coming years which is supported by an increase in profits from principal activity and a decrease of the burden of interest payments. (See Table 3)

Return on Equity (ROE). Return on equity of the project reflects the total equity profit and shows the company's ability to turn assets into profits. 
With the help of ROE, investors can see whether or not they are receiving good profits from the invested capital but the company can evaluate how effectively the company's own capital is being used. The calculation of ROE is most advantageous when it is compared with company's historic ROE indicators or the average ROE indicator in the industry. ROE of some industries is higher than others and therefore it is most valuable in comparing companies within the same industry. A riskier company will demand higher expenses of the capital and own funds. In order to satisfy the demands of investors, the company should be capable of producing a higher return on equity than profits from a lower risk investment.

A disadvantage of return on equity is that some ROE indicators can exclude intangible assets such as trademarks, copyrights and patents from the shareholders' funds. That can make calculations misleading and hard to compare with other companies that have decided to include intangible assets. In the case of this project such a problem should not occur because the company only has one intangible asset the value of which cannot significantly influence the calculations. Inaccuracies can also occur in the own funds position because some analysts use the value at the beginning of the year but some at the end of the year or the average of the two, but the net income can be substituted with EBITDA and EBIT which can be adjusted with one-off items. The author of the research uses net profit and the yearly value of the equity review. Formula for calculating ROE [3.2]:

$$
\text { Return on Equity = Net Income / Equity } \quad * 100 \%
$$

Table 4. Return on Equity from 2020 to 2024, EUR

\begin{tabular}{|l|c|c|c|c|c|}
\hline Period, Year & & & & & \\
\hline Net Profit, EUR & -23383862 & -920817 & -907541 & -904381 & -892758 \\
\hline Equity, EUR & 35616138 & 35155730 & 34241551 & 33335590 & 32437021 \\
\hline ROE, \% & $-65.66 \%$ & $-2.65 \%$ & $-2.69 \%$ & $-2.75 \%$ & $-2.79 \%$ \\
\hline
\end{tabular}

Source: Created by the authors

The significantly negative ROE indicator in 2020 can be explained by the strongly negative amount of undistributed profits. In the following years the indicator is not as negative as in its first operational year but the ROE retains an increasing negative trend. With time, negative return on equity can mean that the company is not capable of showing good shareholder value and increasing productivity and profits by making bad decisions about investing capital in unproductive assets. (See table 4) 
Return on Invested Capital (ROIC). ROIC is the return on invested capital and it is the correlation of profitability the goal of which is to evaluate the profit percentage that the company's investors gain from the invested capital. The correlation reflects how effectively the company is using the investors' funds to generate income.

Return on Invested Capital $=$

Net operating profit after taxes / Invested Capital

Net operating profit after taxes is the same as EBIT*(1-T) where EBIT is the earnings before interest and taxes but $\mathrm{T}$ - the corporate tax rate. As in the project is not planning on distributing the profits in dividends, undertaking expenditures unrelated to economic activity, paying increased interest and will be providing loans to related persons etc., in accordance with Corporate Tax Law (in force from 01.01.2018.) and the Cabinet of Ministers regulation Nr. 677 "Uzṇēmumu ienākuma nodokḷa likuma normu piemērošanas noteikumi" (in force from November 14th, 2017) the company will be exempted from paying the CIT during the prognosed five years. [16] In which case the net operating profit after taxes will be equal to the EBIT.

Table 5. Return on Invested Capital from 2020 to 2024, EUR

\begin{tabular}{|l|c|c|c|c|c|}
\hline Period, Year & & & & & \\
\hline EBIT, EUR & -23365982 & -941874 & -928051 & -926058 & -913849 \\
\hline $\begin{array}{l}\text { Invested } \\
\text { Capital, EUR }\end{array}$ & 35629778 & 34710708 & 33803715 & 32899901 & 32007730 \\
\hline ROIC, \% & $-65.58 \%$ & $-2.71 \%$ & $-2.75 \%$ & $-2.81 \%$ & $-2.86 \%$ \\
\hline
\end{tabular}

Source: Created by the authors

ROIC has a similar trend to that of the ROE. In the beginning it is significantly negative, in the second year of operation it is $-2.71 \%$ and in the following years retains a negative trend. Such a similarity in the results of the indicators is explained by the author by the financing of the project from equity. (See Table 5)

By evaluating all the previous calculations, the authors of the research conclude that the company suffers the biggest losses in the first year of operation because of investments in fixed assets and the high costs of connecting the stations. The situation is better in the upcoming years by comparison to 2020, but the profit and profitability indicators of the company remain negative even with increasing profits. The amortization of fixed assets and intangible investments significantly influences the profits in the upcoming years. 


\section{Risk Analysis}

This project, as well as any other company will operate in a changing environment and will be subject to a variety of uncertainties that create gaps and inaccuracies in the development of future business scenarios and contribute to their unpredictable outcomes. If the uncertainty is a quantitative parameter which cannot be supported by calculations, then the risk is something that can be quantified, predicted, and avoided. The risk is the likelihood of loss due to unforeseen and unfavourable circumstances for the company. [12] The risk management process requires continuous risk identification, evaluation and management. It is not possible to completely avoid the risk, the probability of its occurrence is always present, but by applying risk management, which involves forecasting the causes and consequences of the risks and implementing various measures to reduce the impact of the risks, it is possible to reduce the potential loses brought on by the risks.

The authors have identified 9 major risks that could jeopardize the success of the project and cause both financial and moral damage. The risk profile of the project was established, its management defined, the criteria for event consequences were reviewed, the criteria of probability of events was established, the level of risk, the division of risk factors, and all of these were summarized in the risk matrix. (See Table 6)

Table 6. The Risk Matrix of the Project

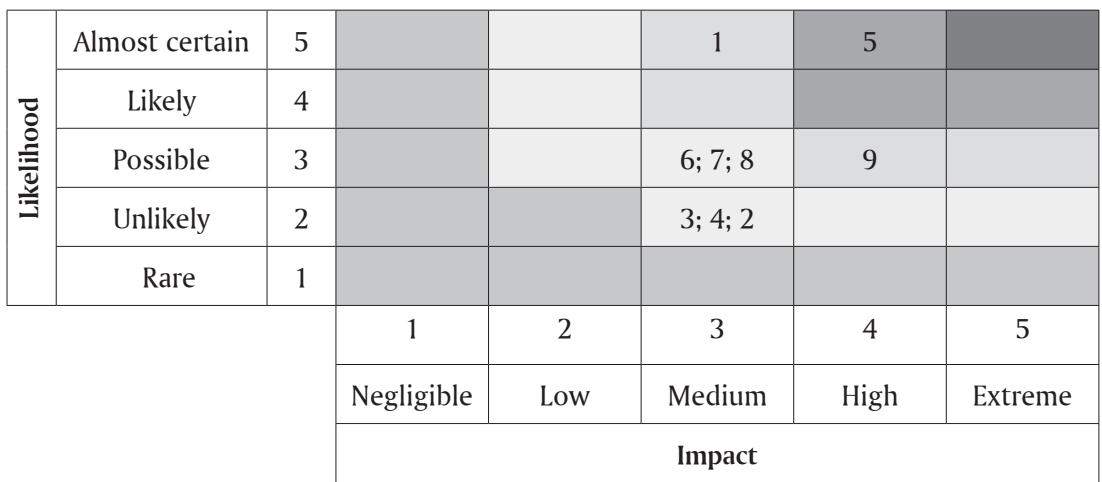

Source: Created by the authors

Summarizing the distribution of the risk matrix, the authors conclude that attention should be paid to the legislative risk, which is a part of the high-risk area, as well as to the price and innovation risks, which are positioned on the medium-risk level. 
Legislative risk, which was part of the high-risk area in the risk matrix, manifests itself in the often-changing legal environment, as well as in the violations of company laws, acts and regulations. The consequences of these events can have a critical impact on the business up until insolvency occurs. [13] [18] In order to reduce the risk of legislation, the authors recommend continually reviewing current developments in legislations and sector-specific regulations and utilizing legal advice.

The medium-risk group included price and innovation risks. The fluctuating electricity market prices in the "Nord Pool" stocks of the Baltic countries' trading areas, fluctuations in the market price of electricity depending on the weather conditions in the Nordic countries, the increase in resource prices on the world markets, and the negative impact of the local weather conditions on electricity generation capacity have a significant impact on electricity prices in the market. There is possible to use different financial contracts, for instance, in NASDAQ Energy Products Forward Market, but in the context of this project it was not used due to the low production volumes. The project implementers will try to make future forecasts as accurate as possible. The biggest challenge when addressing the risk of innovation is the lack of experience in work with innovative production machinery and projects, and the worst consequence of this is the loss of invested funds. Timely and detailed market analysis, a project financial outlook of at least 5 years, and consultations with experienced professionals, agencies and associations can help mitigate this risk.

The low risk group included: manufacturing, operational, accident, liquidity, interest rate and credit risk. It is difficult to influence the occurrence of interest rate risk, but it is possible to try to avoid it by carrying out additional analysis and signing less risky contracts. The operational, production, liquidity and credit risks can be directly addressed as these risks are dependent on the internal factors within the company. The key measures to mitigate these risks include the development of various internal regulations, the use of insurance, the hiring of highly qualified and competent personnel, regular monitoring and the organization of inspections.

Risk management must be implemented throughout the performance of the business activities, with periodic monitoring and review of the situation to ensure that the measures taken against the risks are up to date. It should reflect the product, market, labour, and legislation changes and the current events to promote a safe and forward-looking business.

The authors of the research envision several scenarios for improving the situation. One of such scenarios is a quicker and more significant increase of the electricity prices. It would positively impact the profits 
of this type of project but could, however, encourage a price increase in other industry products and services which could lead to a global problem. Another, is to attract EU foundation programs and other investors. The authors will now explore how other EU countries solve such problems.

\section{Case Study}

With the development of renewable energy, many consumers have also become producers, installing, for example, solar panels or small wind generators to cover their own consumption. RES has a direct link to the weather, resulting in situations when the produced electricity exceeds the subject's consumption and vice versa, the electricity is in deficit. In Germany, power companies such as "E.ON" and "Enerix" offer households, which provide their own electricity consumption, in periods of overcapacity and fully charged batteries to drain excess electricity to the grid. According to the German legislation, households do not receive any income from the deal, but the system works that way, when households are in deficit and use grid electricity, they receive the necessary amount of electricity for free. At the end of the year, the power company recalculates the balance. In case the household produces more electricity than it consumes, it receives a payment of balance difference according to the law on electricity produced from renewable sources (Renewable Energy Act EEG). Otherwise, the household pays the excess electricity according to a market price. If one turns to the, as they are named, "active consumers", then one needs to know that they can be households, individuals, groups of individuals, small businesses, social organizations or municipal authorities, acting individually or organized, such as associations, foundations or cooperatives. [6]

Energy cooperatives in the EU are becoming more popular and common, especially in Denmark, Germany, Belgium, Spain and France. They are working on the different activities and obtain a different service in the energy sector, for example: self-generation and consumption; generation of renewable energy for export to the grid; ownership or operation of storage facilities, micro-grids and other distribution infrastructure for electricity and district heating networks; provision of energy efficiency and other services.

The Renewable Energy Directive (RED) 2018, has defined a 'renewable energy community' term: "A legal entity: i) which, according to applicable national law, is based on open and voluntary participation, is autonomous, and is effectively controlled by shareholders or members that are located in the proximity of the renewable energy projects owned and developed by that community; ii) whose shareholders or members are natural persons, 
local authorities, including municipalities, or SMEs; iii) whose primary purpose is to provide environmental, economic or social community benefits for its members or the local areas where it operates rather than financial profits." [1]

Table 7. Characteristics and Main Challenges of Energy Community Business Models [6] [10] [15]

\begin{tabular}{|c|c|c|c|}
\hline \multicolumn{2}{|c|}{ Business Model } & Characteristics & Main Challenges \\
\hline \multirow{6}{*}{ 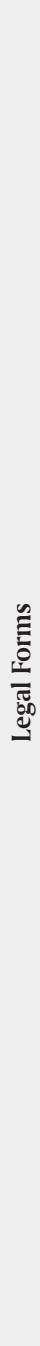 } & Cooperative & $\begin{array}{l}\text { - Democratic culture: open to } \\
\text { everyone; one member = one vote. } \\
\text { - Straight benefit from generated } \\
\text { energy. } \\
\text { - More oriented to social benefits for } \\
\text { society. }\end{array}$ & $\begin{array}{l}\text { - Necessary capital } \\
\text { advance. } \\
\text { - Not enough knowledge } \\
\text { and skill. } \\
\text { - Save of cooperative } \\
\text { values. }\end{array}$ \\
\hline & Partnership & $\begin{array}{l}\text { - Vote weight = stake in a company } \\
\text { capital. } \\
\text { - More oriented to private benefits } \\
\text { and income, but also good for } \\
\text { society. } \\
\text { - Democratic decision making. }\end{array}$ & $\begin{array}{l}\text { - Personal habits, } \\
\text { different management } \\
\text { styles, split of } \\
\text { the liabilities, } \\
\text { communicational } \\
\text { barriers. } \\
\text { - Necessary capital } \\
\text { advance. } \\
\text { - Not enough knowledge } \\
\text { and skill. }\end{array}$ \\
\hline & $\begin{array}{l}\text { Community } \\
\text { Trusts and } \\
\text { Foundations }\end{array}$ & $\begin{array}{l}\text { - Oriented to benefits for society. } \\
\text { - Possibility to receive grants. } \\
\text { - Trust may have no owners or } \\
\text { shareholders. } \\
\text { - Income usually is reinvested into } \\
\text { the community or the organization. }\end{array}$ & $\begin{array}{l}\text { - Necessary capital } \\
\text { advance. } \\
\text { - Hard to receive loans } \\
\text { from banks. } \\
\text { - To make a clear } \\
\text { working mechanism of } \\
\text { the organization. } \\
\text { - Difficulties with } \\
\text { contract signing. }\end{array}$ \\
\hline & $\begin{array}{l}\text { Non- Profit } \\
\text { Customer- } \\
\text { Owned } \\
\text { Enterprises }\end{array}$ & $\begin{array}{l}\text { - Especially good for community } \\
\text { power projects on a small or } \\
\text { independent grid network. } \\
\text { - Governed by a general assembly. } \\
\text { - Is possible to get subsidies- } \\
\text { municipal guarantees, governmental } \\
\text { grants, loans with low interest rates. }\end{array}$ & $\begin{array}{l}\text { - Difficulties with } \\
\text { connection to the grid. } \\
\text { - Not enough knowledge } \\
\text { and skill. }\end{array}$ \\
\hline & $\begin{array}{l}\text { Other socially- } \\
\text { oriented } \\
\text { enterprises }\end{array}$ & $\begin{array}{l}\text { - Charities which support community } \\
\text { or social aims. }\end{array}$ & $\begin{array}{l}\text { - In some countries, } \\
\text { charities are not } \\
\text { recognized as } \\
\text { individual legal } \\
\text { organization. }\end{array}$ \\
\hline & Individuals & $\begin{array}{l}\text { Individuals who not only consume, } \\
\text { but also produce energy and surplus } \\
\text { energy drain to the grid. }\end{array}$ & $\begin{array}{l}\text { - Existence of the system } \\
\text { at the legislative and } \\
\text { technical levels. }\end{array}$ \\
\hline
\end{tabular}




\begin{tabular}{|c|c|c|c|}
\hline \multicolumn{2}{|r|}{ Business Model } & Characteristics & Main Challenges \\
\hline \multirow{2}{*}{ 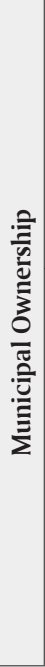 } & $\begin{array}{l}\text { Public Utility } \\
\text { Company }\end{array}$ & $\begin{array}{l}\text { Provides an infrastructure for } \\
\text { a public service. } \\
\text { - Often are natural monopolies. }\end{array}$ & $\begin{array}{l}\text { - Legislation and strict } \\
\text { regulation. } \\
\text { - Aging infrastructure. } \\
\text { - New and emerging } \\
\text { technologies. } \\
\text { - Changing demand. } \\
\text { - Lack of qualified human } \\
\text { capital. }\end{array}$ \\
\hline & $\begin{array}{l}\text { Cooperation } \\
\text { between } \\
\text { municipalities: } \\
\text { public-public } \\
\text { partnerships }\end{array}$ & $\begin{array}{l}\text { - Some municipalities can join to } \\
\text { create co-operatives. } \\
\text { - More new opportunities in regional } \\
\text { level. } \\
\text { - Aims can be: independence of fossil } \\
\text { fuels, renewable energy accessibility } \\
\text { for individuals and popularity of } \\
\text { such projects. } \\
\text { - Members can be only municipalities } \\
\text { and corporate organizations under } \\
\text { public law (excluding private } \\
\text { companies and associations). }\end{array}$ & $\begin{array}{l}\text { - Necessary capital } \\
\text { advance. } \\
\text { - To reach a compromise } \\
\text { in different questions. } \\
\text { - Support of the citizens } \\
\text { in the certain } \\
\text { municipality. }\end{array}$ \\
\hline & $\begin{array}{l}\text { ublic- Private } \\
\text { Partnership }\end{array}$ & $\begin{array}{l}\text { - Run by municipalities. } \\
\text { - Authorities can help to decrease } \\
\text { initial investments, provide grands, } \\
\text { taxation relief. } \\
\text { - Risk-sharing between public and } \\
\text { private sectors. } \\
\text { - Public service and ultimate } \\
\text { regulatory responsibility is on public } \\
\text { sector. }\end{array}$ & $\begin{array}{l}\text { - } \text { Conflicting aims. } \\
\text { legislation mostly is } \\
\text { oriented to public } \\
\text { sector responsibility } \\
\text { in infrastructure and } \\
\text { insignificantly manages } \\
\text { private participation. } \\
\text { - Public governance } \\
\text { uncertainty about } \\
\text { tariffs, prices, rules, } \\
\text { objectives etc. } \\
\text { - Lack of qualified human } \\
\text { capital. } \\
\text { - Corruption. }\end{array}$ \\
\hline
\end{tabular}

There is a variety of models for renewable energy communities. To choose the most appropriate form, entrepreneurs need to take in consideration many factors such as: community demand, availability of resources, stakeholders involved, mission, aims and strategy, financing etc. On the basis on these factors, community can be not-for-profit or profit-making. The main goal of a non-profit community is offering cheap or discounted energy for its target market (for example, rural community) and a profit-making - make additional income. The main legal forms for renewable energy communities are co-operative, partnership, trust and foundations, public utility company, public-private partnership. 
Each of these forms has certain strengths and weaknesses, but some of them are common. One of the important cornerstones of a renewable energy topic is an access to capital investments. Renewable energy technologies have become more competitive (in terms of cost), but the cost of projects is still very high to realise without financial support. Other topic to think about is a society support. Many researches and surveys were made on this topic, but there still does not exist certain opinion - part of a society support and other does not, but each has its own arguments. One more thing what can be referred to all of the mentioned above models is lack of qualified human capital, who can work with new technologies, models and keep up with market changes.

If one turns to the Latvian case, there is only few such business model examples. For now Latvia is on the way of cooperation with banks, EU fonds, but not communities, municipalities, individual customers. In the energy legislation of Latvia is a definition of 'autonomous producer' which has only tax incentives for RE installations, but doesn't have support mechanisms, priority access to the grid, simplified permitting procedures for RE installation. If one looks at the other Baltic States, then Estonia is offering support mechanisms and simplified permitting procedures for RE installations, but Lithuania, in addition to the Estonian list, is offering also tax incentives and priority access to the grid.

The project of a cooperative between an energy company and, for instance, municipality in Latvia, can be a topic for the next research.

\section{Conclusions and Recommendations}

As it was already mentioned, the energy system decentralization is on its active stage, what positively effects renewable energy developing, becoming more accessible even for individuals and motivating even more consumers become active. There is a sufficient potential and wind resource to develop wind energy production and renewable energy in general and increase the total installed capacity of renewable energy generators. There is also room for information and experience - wind energy and other RES are very topical and well developed in the European Union to serve as a model. Even many countries do not have specific regulation for raising energy communities, various energy ownership forms are developing across the EU. These communities have certain benefits for society, for example:

- cleaner environment (reducing greenhouse gas emission),

- energy market decentralization and democracy (self-sufficiency, community cohesion),

- economic development (new jobs, cheaper energy),

- energy security, 
but they also face different challenges. The main challenges are:

- unstable legal and regulatory framework and lack of common approaches for supporting community energy;

- market scheme rules and limitations that can be discriminative for smaller market participants;

- many administrative and regulatory challenges for new energy market participants;

- lack of information, instructions and access to finance for local energy communities.

Analysing all the finding above, the authors came out with some recommendation that can positively affect renewable energy development all over the world and make it more common and accessible for everyone who is interested in. So, to improve the situation:

- national policy-makers and governance need to make a stable legal and regulatory framework for renewable energy and to assume more concrete actions to promote the development of local energy communities;

- financial support - it can be grants, low-interest loans, investments and tax relief at a municipal level;

- smart guidance with educational and regulatory help;

- popularisation of renewable energy and society informing.

This development will face enough of challenges, but the positive thing is a good background and experience of EU countries, which can be used as an example how to develop new business models in energy sector and solve different kind of complexities on the way to novelty.

Summarising the above, authors conclude that renewable energy sources are becoming more developed, topical and its demand is growing every year. These facts should be taken into consideration not only by the energy industry and policy makers, but by every producer and consumer. Renewable energy sources help meet demand for clean and affordable energy. Thanks to technological advances and efficiency gains, renewables are becoming more stable and more integrated into the energy system, and vice verses, energy system is becoming more decentralized and open to changes.

\section{REFERENCES}

1. Directive (EU) 2018/2001 of the European Parliament and of the Council of 11 December 2018 on the promotion of the use of energy from renewable sources. Available at: https://eur-lex.europa.eu/legal-content/EN/TXT/?uri=uriserv:OJ.L_. 2018.328.01.0082.01.ENG [Accessed on 28 January 2020]

2. Energy BrainBlog. Trends in the development of electricity prices - EU Energy Outlook 2050. 15 June, 2017. Available at: https://blog.energybrainpool.com/ 
en/trends-in-the-development-of-electricity-prices-eu-energy-outlook-2050/ [Accessed on 30 November 2019]

3. European Commission. Europe leads the global clean energy transition; latest Eurostat data confirms. Published 12 February 2019. Available at: https://ec.europa. eu/info/news/europe-leads-global-clean-energy-transition-latest-eurostat-dataconfirms-2019-feb-12 en [Accessed on 30 October 2019]

4. European Commission. List of NACE codes. Available at: https:/ec.europa.eu/ competition/mergers/cases/index/nace_all.html [Accessed on 27 September 2019]

5. European Commission. 2030 Energy Strategy. Available at: https:/ec.europa. eu/energy/en/topics/energy-strategy-and-energy-union/2030-energy-strategy [Accessed on 24 October 2019]

6. European Committee of the Regions, Commission for the Environment, Climate Changes and Energy. Models of Local Energy Ownership and the Role of Local Energy Communities in Energy Transition in Europe, 2018. Available at: https:// op.europa.eu/en/publication-detail/-/publication/667d5014-c2ce-11e8-942401aa75ed71a1/language-en/format-PDF/source-77208198 [Accessed on 16 February 2020]

7. Central Statistical Bureau of Latvia. Available at: www.csb.gov.lv/en [Accessed on 7 October 2019]

8. Corporate Finance Institute, Available at: www.corporatefinanceinstitute.com [Accessed on 11 November 2019]

9. Dansk Energi. Electricity Price Outlook 2018. Green transition of the electricity system in North western Europe. Available at: https:/www.danskenergi.dk/sites/ danskenergi.dk/files/media/dokumenter/2018-06/Electricity_Price_Outlook_2018. pdf [Accessed on 26 December 2019]

10. Interreg Europe. Renewable Energy Communities. A Policy Brief from the Policy Learning Platform on Low-carbon Economy. August 2018. Available at: https:// www.interregeurope.eu/fileadmin/user_upload/plp_uploads/policy_briefs/ 2018-08-30_Policy_brief_Renewable_Energy_Communities_PB_TO4_final.pdf [Accessed on 27 February 2020]

11. JSC "Augstsprieguma tīkls". Latvian electricity market overview. Available at: http:// www.ast.lv/en/electricity-market-review?year $=2017 \&$ month $=10$ [Accessed on 19 October 2019]

12. Latvian Academy of Sciences. Terminology commission. Risk. Available at: http://termini.lza.lv/term.php?term $=$ risks\&list $=$ risks\&lang $=\mathrm{LV} \quad$ [Accessed on 15 November 2019]

13. Legal acts of the Republic of Latvia. Electricity Market Law. Available at: https:// likumi.lv/ta/en/en/id/108834-electricity-market-law [Accessed on 19 January 2020]

14. Monger, R. (2010). Financial Accounting: a Global Approach. WILEY.

15. Roberts, J., Bodman, F. and Rybski, R. (2014). Community Power: Model Legal Frameworks for Citizen-owned Renewable Energy. (ClientEarth: London). Available at: https://ec.europa.eu/energy/intelligent/projects/sites/iee-projects/files/projects/ documents/model_legal_frameworks_2014.pdf [Accessed on 5 March 2020]

16. State Revenue Service of Republic of Latvia. Available at: https://www.vid.gov.lv/en [Accessed on 11 November 2019] 
17. The Latvian Energy Efficiency Association (LATEA). Energy Strategy for 2030. Available at: http://www.latea.lv/userfiles/news/14122011_Energetikas_strategija_ 2030.pdf [Accessed on 14 October 2019]

18. The Public Utilities Commission. REMIT. Available at: https:/www.sprk.gov.lv/ index.php/content/remit-0 [Accessed on 19 January 2020]

19. The Wind Power database. Production Capacities. Available at: https://www. thewindpower.net/country_en_42_latvia.php [Accessed on 10 October 2019]

20. Wind Energy Association of Republic of Latvia. About The Renewable Energy. Available at: http://www.vejaenergija.lv/about-energy [Accessed on 10 October 2019] 